\title{
Pemberdayaan Masyarakat dalam Pemahaman Tentang Akad Kafalah Berdasarkan Kompilasi Hukum Ekonomi Syariah (KHES) di Desa Pandau Jaya Kecamatan Siak Hulu
}

\author{
Muhammad Azani ${ }^{1}$, Hasan Basri ${ }^{2}$ \\ 1) 2) Universitas Lancang Kuning, Pekanbaru, Indonesia \\ MEmail : $\underline{\text { mhd.azani@unilak.ac.id }}$
}

\begin{tabular}{l|l|l} 
Received: 09-01-2021 | Revised: 07-03-2020 | Accepted: 04-04-2021
\end{tabular}

\begin{abstract}
:
The results of community service in the form of legal counseling in Pandau Jaya Village, Siak Hulu District are as follows: Has increased participants' understanding of the Kafalah contract in the Sharia Economic Law Compilation (KHES). The material presented includes the pillars of the kafalah contract, the terms for the object of the kafalah contract, the types of the kafalah contract, the implementation of the kafalah contract, and the parties who die in the kafalah contract. After delivering the material, participants were asked a number of questions related to the material presented. The distribution of participants' answers after legal counseling can be stated that participants understand the material presented. In general, participants can understand the kafalah contract in KHES. There were 6 (six) questions given, question number 3 about the type of kafalah contract and number 5 about the guarantor who passed away received the highest answers with $84 \%$ and $85 \%$. Problems that arise in the form of participant questions are questions about the difference between the kafalah contract and the rahn contract as a guarantee contract and questions about the pillars of the kafalah contract. Kafalah is the equivalent of dhamman, which means guarantee, but in its development, Kafalah is identical to kafalah al-wajhi (personal guarantee, self-guarantee), while dhamman is identical to collateral in the form of goods / assets. This concept is different from akad rahn which means collateral, but collateral from the person in debt. In addition, questions about the pillars of the kafalah contract, the answer refers to Article 22 KHES 335 which states that the pillars of the kafalah contract are the guarantor (Kafil), the guaranteed party (Makful 'Anhu), the indebted party (Makful Lahu), the object (Makful Bihi), and Akad. The kafalah contract in sharia banking activities is used as a form of bank service to guarantee activities or businesses proposed by customers. Guarantee in the form of kafalah can be carried out with the model of asset guarantee (kafalah bi al-mal) and person / institution guarantee (kafalah bi al-nafs). Financially or institutionally, the bank guarantees the party applying for guarantee services.
\end{abstract}

Keyword: Contract of Kafalah, and Islamic Law

\section{Pendahuluan}

Dalam hubungan muamalah antarmanusia terdapat transasksi ekonomi yang dilakukan dalam memenuhi kebutuhan sehari-hari. Kehidupan ekonomi masyarakat di Desa Pandau Jaya juga mengalami bentuk-bentuk transaksi dalam peningkatan ekonomi mereka, mulai dari transaksi jual beli maupun transaksi kredit. Dalam Hukum Islam, teori majlis akad diperbolehkan baik para pihak dapat bertransaksi dengan tata muka 
maupun dengan jarak jauh, selama para pihak tetp fokus pada objek transaksi yang sama (Syamsul Anwar, 2007).

Kenyataan yang demikian menjadi kontras dan bertentangan bila dikaitkan dengan sistem jual beli dalam hukum Islam. (Syamsul Anwar, 2007). Dalam transaksi jual beli, hukum Islam menuntut adanya kejelasan, terhindar dari spekulasi dan didasarkan pada perhitungan kuantitas yang jelas terhadap objek penjualan (Ahmad Dimyati, 2007 dan Marabona Munthe, 2012).

Kelompok mitra yang dijadikan sasaran kegiatan merupakan kelompok masyarakat umum yang berprofesi sebagai pedagang dan pekerja lepas. Bagi kelompok masyarakat itu sangat penting untuk mendapat pemahaman yang benar tentang akad kafalah yang benar berdasarkan hukum Islam. Menurut pengakuan mereka yang sering terlibat dalam kegiatan penjaminan itu kurang dapat memahami dengan baik bentuk akad kafalah yang benar sesuai ajaran agama.

Minimnya pemahaman mereka tentang akad kafalah berdasarkan hukum Islam karena selama ini penjaminan yang mereka lakukan sesuai kebiasaan yang ada sebelumnya. Terlebih lagi masyarakat pada umumnya telah biasa melakukan praktik kafalah namun akad yang dilakukan tidak sesuai dengan KHES. Pengabaian nilai kemashlahatan itu menjadikan akad kafalah itu seringkali tidak sesuai dengan ajaran agama.

\section{Metode Pelaksanaan}

\section{Metode Pelaksanaan}

Dalam menyelesaiakan permasalahan mitra, telah disepakati bersama bahwa kegiatan yang dilaksanakan adalah penyuluhan hukum. Penyampaian materi oleh dosen yang tergabung dalam Tim pengusul kegiatan. Selaian itu, juga melibatkan kepala Desa sebagai fasilitator kegiatan.

Rangkaian kegiatan yang dilaksanakan dalam rangka kegiatan pengabdian kepada masyarakat menggunakan dua metode, yaitu 1) Ceramah atau penyuluhan. Dalam metode ini peneceramah atau penyuluh menyampaikan materi tentang Akad Kafalah berdasarkan KHES. Dalam kesempatan itu peserta dibebaskan untuk bertanya jawab dengan penceramah. Rincian dari metode ini adalah pemaparan tentang Akad Kafalah berdasarkan KHES. 2) Dialog interaktif, dalam hal ini peserta diposisikan sebagai subjek yang dapat memberikan ulasan terkait dengan problematika Akad Kafalah berdasarkan KHES. Dialog ini sebagai curah pendapat (brainstorming) untuk memperoleh masukan berupa persoalan, aspirasi, usulan, gagasan dan solusi sebanyak-banyaknya dari para peserta. 3) Evaluasi pemahaman dengan menyebarkan kuesioner kepada peserta pada saat sebelum dan sesudah kegiatan. Tujuan kuesioner untuk mengetahui tingkat pemahaman peserta tentang Akad Kafalah berdasarkan KHES.

Evaluasi kegiatan dilakukan dengan banyaknya jumlah peserta yang hadir minimal $50 \%$ dari jumlah undangan yang disebar. Antusiasme peserta kegiatan selama pengabdian berlangsung menjadi indikator kebrhasilan pengabdian ini. 
Dalam kegiatan ini, prosedur kerja dilaksanakan dengan beberapa tahap, yaitu sebagai berikut:

Penyuluhan Hukum tentang

Akad kafalah yang dilakukan oleh Pengabdi

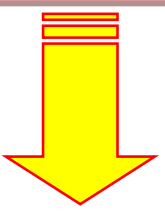

Evaluasi pemahaman peserta pada materi yang disampaikan dalam pengabdian

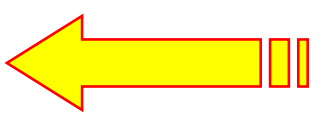

Persiapan, Kunjungan ke

Lokasi kegiatan, dan perancangan Modul

Penyuluhan Hukum

Penulisan laporan Pengabdian dan luaran pengabdian

\section{Jadwal kegiatan}

Tahapan dan rangkaian program Pengabdian masyarakat dan waktu pelaksanaannya sebagai berikut

\begin{tabular}{|c|c|c|c|c|c|c|c|c|c|c|c|c|c|}
\hline \multirow{2}{*}{ No } & \multirow{2}{*}{ Jenias kegiatan } & \multicolumn{4}{|c|}{ September } & \multicolumn{4}{|c|}{ Oktober } & \multicolumn{4}{|c|}{ November } \\
\hline & & 1 & 2 & 3 & 4 & 1 & 2 & 3 & 4 & 1 & 2 & 3 & 4 \\
\hline 1 & Melakukan koordinasi dengan Pihak Desa & & & & & & & & & & & & \\
\hline 2 & Menyebarkan undangan ke peserta kegiatan & & & & & & & & & & & & \\
\hline 3 & Melaksanakan Penyuluhan Hukum & & & & & & & & & & & & \\
\hline 4 & $\begin{array}{l}\text { Melaksanakan konsultasi dan pendalaman } \\
\text { materi akad kafalah }\end{array}$ & & & & & & & & & & & & \\
\hline 5 & Monitoring dan evaluasi pemahaman mitra & & & & & & & & & & & & \\
\hline 6 & Pembuatan Laporan & & & & & & & & & & & & \\
\hline 7 & $\begin{array}{l}\text { Medsos, Poster, Proceding dan Jurnal } \\
\text { pengabdian masyarakat atau luaran lainnya }\end{array}$ & & & & & & & & & & & & \\
\hline
\end{tabular}

\section{Hasil dan Pembahasan}

\section{Pelaksanaan Pengabdian}

a) Pemberian materi tentang Akad Kafalah

Pelaksanaan penyuluhan menggunakan metode ceramah dan dialog. Sesi pertama menggunakan metode ceramah. Pemateri menyampaikan bahan/materi dalam bentuk slide power point tentang Peningkatan Pemahaman Masyarakat Tentang Akad Kafalah Berdasarkan Kompilasi Hukum Ekonomi Syariah (KHES) Di Desa Pandau Jaya Kecamatan Siak Hulu. Peserta menyimak materi yang disampaikan 
pemateri. Setelah peserta diberikan materi, peserta diberikan kuisioner dengan beberapa pertanyaan tentang Peningkatan Pemahaman Masyarakat Tentang Akad Kafalah Berdasarkan Kompilasi Hukum Ekonomi Syariah (KHES). Jawaban yang benar pada kuisioner itu terdapat materi yang disampaikan pemateri. Tujuan kuisioner setelah penyampaian materi ialah mengukur pengetahuan peserta. Jumlah peserta yang hadir dalam kegiatan tersebut sebanyak 17 (tujuh belas) orang. Jumlah yang hadir dihitung dari absen yang disediakan.

\section{b) Evaluasi kegiatan}

Evaluasi penyuluhan menggunakan metode kuisioner/angket berjumlah 6 (enam) pertanyaan. Kuisioner dibagi sesudah materi disampaikan. Tujuannya ialah untuk mengetahui peningkatan pemahaman peserta pada saat materi sesudah disampaikan. Pemahaman mereka dapat dilihat pada setiap pertanyaan kuesioner sekaligus jawaban peserta. Evaluasi berikut dilakukan untuk mengetahui pengetahuan peserta kegiatan tentang Peningkatan Pemahaman Masyarakat tentang akad kafalah Berdasarkan Kompilasi Hukum Ekonomi Syariah (KHES) setelah dilakukan penyuluhan hukum. Kuisiner pertama mengenai pertanyaan sebutkan rukun akad kafalah menurut KHES? Pilihan jawaban atas pertanyaan tersebut adalah (A). Penjamin (Kafil), Pihak yang dijamin (Makful 'Anhu), Pihak yang berpiutang (Makful Lahu), Objek (Makful Bihi), dan Akad. (B). Objek (Makful Bihi), dan Akad. Jawaban yang benar adalah (A). Penjamin (Kafil), Pihak yang dijamin (Makful 'Anhu), Pihak yang berpiutang (Makful Lahu), Objek (Makful Bihi), dan Akad. Pihak yang menyewa, Pihak yang menyewakan, Benda yang diijarahkan, dan Akad (A). Rukun ini didasarkan pada Pasal 22 KHES 335. Pelaksanaan rukun akad kafalah harus dinyatakan para pihak baik dengan lisan, tulisan, atau isyarat. Peserta yang menjawab dengan benar sebanyak $72 \%$, sedangkan $28 \%$ menjawab salah.

Pengetahuan peserta tentang syarat objek akad kafalah dapat dievaluasi dari pertanyaan Apakah syarat objek yang harus terpenuhi menurut KHES? Pilihan jawaban persebut (A). Merupakan tanggungan peminjam baik berupa uang, benda, atau pekerjaan, dapat dilaksanakan oleh penjamin, merupakan piutang mengikat/lazim yang tidak mungkin hapus kecuali setelah dibayar atau dibebaskan, jelas nilai, jumlah, dan spesifikasinya, tidak diharamkan. (B). Jelas nilai, jumlah, dan spesifikasinya, dan tidak diharamkan.

Rata-rata peserta kegiatan dapat menjawab pertanyaan dengan benar sebanyak $83 \%$ pada jawaban (A). Merupakan tanggungan peminjam baik berupa uang, benda, atau pekerjaan, dapat dilaksanakan oleh penjamin, merupakan piutang mengikat/lazim yang tidak mungkin hapus kecuali setelah dibayar atau dibebaskan, jelas nilai, jumlah, dan spesifikasinya, tidak diharamkan, B, yakni Dapat dibatalkan berdasarkan kesepakatan. Jawaban ini didasarkan pada Pasal 338 KHES.

Pemahaman peserta tentang jenis akad kafalah dapat dibaca dari jawaban mereka tentang pertanyaan sebutkan jenis akad kafalah dalam KHES! Pilihan jawaban (A). Akad Kafalah Mutlaqah (B). Akad Kafalah Mutlaqah dan Akad Kafalah Muqayyadah. 
Sebagian besar peserta telah memahami bahwa jenis akad kafalah adalah kafalah mutlaqah dan Kafalah Muqayyadah (B). Pasal 342 KHES menyebutkan bahwa dapat Kafalah dapat dilakukan dengan muthlaqah/tidak dengan syarat atau muaqayyadah/dengan syarat. Dalam akad kafalah yang tidak terikat persyaratan, kafalah dapat segera dituntut apabila utang itu harus segera dibayar oleh debitor. Dalam akad kafalah yang terikat persyaratan, penjamin tidak dapat dituntut untuk membayar sampai syarat itu di penuhi (Pasal 343 dan 344 KHES). Dalam evaluasi ini, $84 \%$ peserta dapat menjawab dengan benar, sedangkan $16 \%$ menjawab salah.

Dalam pelaksanaan akad kafalah, pemahaman peserta tentang materi ini dapat dilihat dari pertanyaan berikut: Sebutkan jenis pelaksanaan akad kafalah dalam KHES? (A). Kafalah atas Diri, (B). Kafalah atas Diri dan Harta. Jawaban peserta dapat dibaca pada gambar berikut:

Jawaban yang benar evaluasi di atas adalah pada poin (B), Kafalah atas Diri dan Harta. Sebanyak 68 \% peserta dapat memahami pelaksanaan akad kafalah. Pasal 347 KHES menyebutkan bahwa akad kafalah terdiri atas kafalah diri dan kafalah harta. Dalam Pasal 348 ditegaskan bahwa Ayat (1) Pihak pemberi pinjaman memiliki hak memilih untuk menuntut pada penjamin atau kepada pihak peminjam, Ayat (2) Dalam melaksanakan hak tersebut kepada salah satu pihak dari kedua pihak itu tidak berarti bahwa pihak pemberi pinjaman kehilangan hak terhadap yang lainnya.

Dalam akad kafalah, KHES mengatur tentang penjamin yang meninggal dunia. Pertanyaan kepada peserta adalah bagaimana jika penjamin meninggal dunia dalam KHES? Pertanyaan tersebut memiliki dua pilihan jawaban (A). Ahli waris berkewajiban untuk menggantikannya atau menunjuk penggantinya (B). Ahli waris tidak melakukan tindakan hukum. Peserta dapat menjawab dengan benar sebanyak $85 \%$ pada jawaban (A), yakni Ahli waris berkewajiban untuk menggantikannya atau menunjuk penggantinya. Dalam Pasal 351 KHES diatur bahwa Ayat (1) Apabila penjamin meninggal dunia, ahli warisnya berkewajiban untuk menggantikannya atau menunjuk penggantinya, Ayat (2) Apabila ahli waris gagal dalam menghadirkan peminjam, maka harta peninggalan penjamin harus digunakan untuk membayar utang yang dijaminnya.

Pertanyaan berikutnya dalam kuisioner adalah bagaimanakah jika pemberi pinjaman meninggal dunia menurut KHES? (A). Ahli waris dapat menuntut sejumlah uang jaminan kepada penjamin, (B), Ahli waris tidak dapat menuntut sejumlah uang jaminan kepada penjamin. Peserta dapat memahami bahwa Ahli waris dapat menuntut sejumlah uang jaminan kepada penjamin (A). $83 \%$ peserta dapat menjawab dengan benar. Pasal 351 Ayat (3) Apabila pemberi pinjaman meninggal dunia, maka ahli warisnya dapat menuntut sejumlah uang jaminan kepada penjamin. 


\section{Problematika Akad Kafalah (Penjaminan) dalam Praktik Di Masyarakat Desa Pandau Jaya Kecamatan Siak Hulu}

\section{a) Perbedaan Akad Kafalah dan Akad Rahn Sebagai Akad Penjaminan dalam Hukum Islam}

Dalam pelaksanaan pengabdian kepada masyarakat, terdapat ragam persoalan hukum yang diungkapkan oleh peserta dalam bentuk pertanyaan. Pertenyaan yang muncul ada kalanya peserta ingin mengetahui jawaban secara teoritis mapun praktik. Seorang peserta bernama Halimah menanyakan apakah berbedaan antara akad kafalah dan akad rahn? Menurut pemahaman Halimah bahwa kedua akad ini samasama sebagai akad jaminan. Praktik di masyarakat sering kali terjadi bahwa akad penjaminan tidak dibedakan antara akad kafalah dan akad rahn.

Jawaban atas pertanyaan ini penulis kemukan berdasarkan sumber-sumber dalam hukum Islam. Dalam hukum Islam, akad penjaminan terdiri atas jaminan yang berupa orang (personal guarancy) yang dikenal dengan akad kafalah dan jaminan yang berupa harta benda yang dikenal dengan akad rahn. Secara bahasa, Kafalah berasal dari kata kafala, sinonimdengan dhamina (menanggung) (Wahbah Zuhaili, 2002: 114), adh-dhammu (mengumpulkan), hamalah (beban), dan za'amah (tanggungan) (Hendi Suhendi, 2010: 180). Para ahli hukum Islam menyatakan bahwa kafalah adalah Jaminan yang diberikan oleh penanggung (kâfîl) kepada pihak ketigapihak yangjmemberikan hutang/kreditor-(makfûl lahu) untuk memenuhi kewajiban pihak kedua-pihak yang berhutang/debitor-atau yang ditanggung (makfûl 'anhu, ashil) (M. Syafi'i Antonio, 2001: 123).

Adiwarman Karim menegaskan bahwa kafalah menjadi padanan dari dhamman, yang berarti penjaminan, namun dalam perkembangannya, Kafalah identik dengan kafalah al-wajhi (personal guarantee, jaminan diri), sedangkan dhamman identik dengan jaminan yang berbentuk barang/harta benda (Adiwarman Karim, 2001: 106). Konsep ini berbeda dengan akad rahn yang bermakna barang jaminan, namun barang jaminan dari orang yang berhutang.

Jawaban terhadap perbedaan akad kafalah dan akad rahn menjadikan seorang peserta atas nama Suryanita menyampaikan pertanyaan tentang apakah yang menjadi dasar hukum akad kafalah? Penulis memberikan jawaban bahwa dasar hukum untuk akad kafalah terdapat dalam Q.S surat Yûsuf (12) Ayat (66):

"Nabi Ya'kub berkata: 'Aku sekali-kali tidak akan melepaskannya (pergi) bersama-sama kamu, sebelum kamu memberikan kepadaku janji yang teguh atas nama Allah, bahwa kamu pasti akan membawanya kembali kepadaku...". Pada ayat (72) disebutkan, "Penyerupenyeru itu berkata: 'Kami kehilangan piala raja, dan siapa yang dapatmengembalikannya akan memperoleh bahan makanan (seberat) beban unta, dan aku menjamin terhadapnya."1

Dalam riwayat Jabir bin Abdullah ra. berkata: Kepada Nabi SAW pernah didatangkan sesosok jenazah agar beliau menshalatkannya. Lalu beliau bertanya, "Apakah ia punya hutang?" Para Sahabat berkata, "Benar, dua dinar." Beliau bersabda, "Shalatkan teman kalian!" Kemudian Abu Qatadah berkata, "Keduanya (dua dinar itu) menjadi

\footnotetext{
${ }^{1}$ Q.S. Yûsuf [12]:66 dan 72.
} 
kewajibanku, ya Rasulullah." Nabi saw pun lalu menshalatkannya (HR Ahmad, Abu Dawud, an-Nasa'I dan al-Hakim). Imam al-Bukhari meriwayatkan hadis ini dari Salamah bin al-Akwa' dan disebutkan bahwa utangnya tiga dinar. Di dalam riwayat Ibn Majah dari Anu Qatadah, ia ketika itu berkata, "Wa ana attakaffaiu bihi (Aku yang menanggungnya)," Di dalam riwayat al-Hakim dari Jabir di atas terdapat tambahan sesudahnya: Nabi bersabda kepada Abu Qatadah, "Keduanya menjadi kewajibanmu dan di dalam hartamu sedangkan mayit tersebut terbebas?" Abu Qatadah menjawab, "Benar." Lalu Nabi saw menshalatkannya. Saat bertemu Abu Qatadah Rasul saw bertanya, "Apa yang telah dilakukan oleh dua dinar?" Akhirnya Abu Qatadah berkata, "Aku telah membayar keduanya, ya Rasulullah." Nabi saw bersabda, "Sekarang engkau telah mendinginkan kulitnya." (HR al-Hakim). Dalam hadits lain diriwayatkan bahwa Rasulullah SAW bersabda: "Hutang itu harus ditunaikan, dan orang yang menanggung itu harus membayarnya." (HR Abu Daud dan Tirmidzi dan dishakhihkan oleh Ibni Hibban).

\section{b) Akad Kafalah Dalam Praktik di Perbankan Syariah}

Akad kafalah dalam kegiatan perbankan syariah digunakan sebagai salah satu bentuk jasa bank untuk menjamin kegiatan atau usaha yang diajukan oleh nasabah. Penjaminan dalam bentuk kafalah dapat dilakukan dengan model jaminan harta (kafalah bi al-mal) dan jaminan orang/lembaga (kafalah bi al-nafs). Secara finansial atau kelembagaan bank menjamin pihak yang mengajukan jasa penjaminan tersebut (Ali al-Khafif, 2000: 193-194).

Tabel 1 Produk dengan Akad Kafalah

\begin{tabular}{cc}
\hline No & Nama Produk \\
\hline 1 & Jasa Kafalah \\
2 & Syariah charge card \\
3 & Pembiayaan Multi Jasa \\
4 & Syariah Card \\
5 & LC dengan Kafalah bi Ujrah \\
6 & Penjaminan Syariah \\
\hline
\end{tabular}

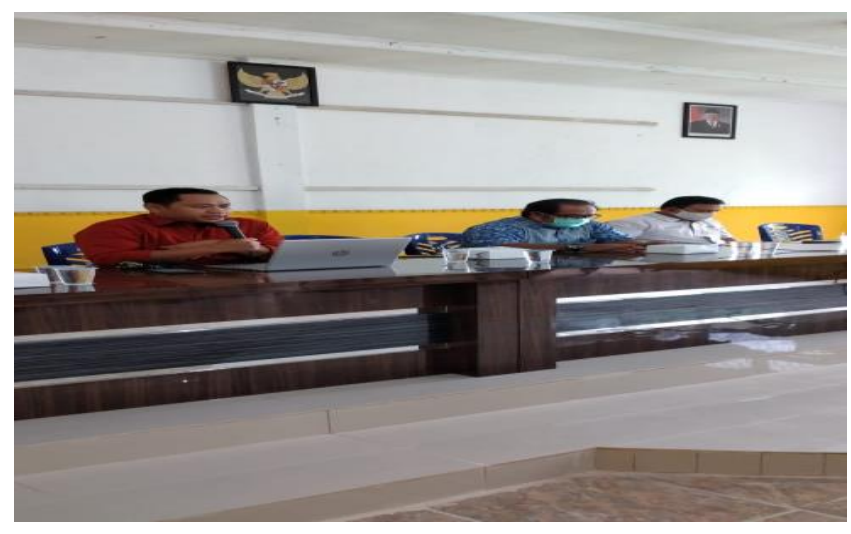

Gambar 1.

Pemateri Sedang Menyampaikan Presentasi tentang Peningkatan Pemahaman Masyarakat Tentang Akad Kafalah Berdasarkan Kompilasi Hukum Ekonomi Syariah (KHES) Di Desa Pandau Jaya Kecamatan Siak Hulu 


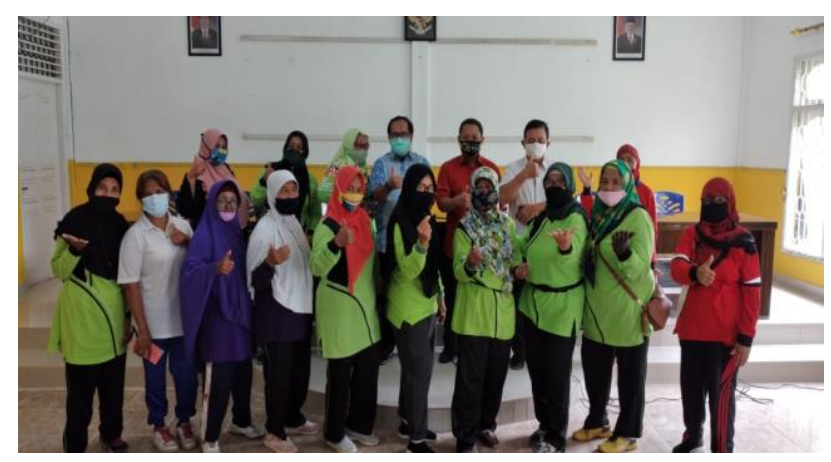

Foto 2

Foto bersama dengan peserta kegiatan setelah kegiatan pengabdian

\section{Kesimpulan}

Hasil pengabdian kepada masyarakat dalam bentuk penyuluhan hukum di Desa Pandau Jaya Kecamatan Siak Hulu dapat disimpulkan sebagai berikut:

1) Telah meningkatkan pemahaman peserta tentang akad Kafalah dalam Kompilasi Hukum Ekonomi Syariah (KHES). Materi yang disampaikan meliputi rukun akad kafalah, Syarat objek akad kafalah, jenis akad kafalah, pelaksanaan akad kafalah, dan para pihak yang meninggal dunia dalam akad kafalah. Setelah penyampaian materi, peserta diberikan sejumlah pertanyaan terkait materi yang disampaikan. Sebaran jawaban peserta setelah penyuluhan hukum dapat dinyatakan bahwa peserta memahami materi yang disampaikan. Secara umum, peserta dapat memahami akad kafalah dalam KHES. Terdapat 6 (enam) pertanyaan yang diberikan, pertanyaan nomor 3 tentang jenis akad kafalah dan nomor 5 tentang penjamin yang meninggal dunia mendapat jawaban tertinggi dengan $84 \%$ dan $85 \%$.

2) Problem yang muncul dalam bentuk pertanyaan peserta adalah pertanyaan tentang perbedaan akad kafalah dan akad rahn sebagai akad jaminan dan pertanyaan tentang rukun akad kafalah. Kafalah menjadi padanan dari dhamman, yang berarti penjaminan, namun dalam perkembangannya, Kafalah identik dengan kafalah al-wajhi (personal guarantee, jaminan diri), sedangkan dhamman identik dengan jaminan yang berbentuk barang/harta benda. Konsep ini berbeda dengan akad rahn yang bermakna barang jaminan, namun barang jaminan dari orang yang berhutang. Selain itu, pertanyaan tentang rukun akad kafalah, jawaban merujuk pada Pasal 22 KHES 335 yang menyatakan bahwa rukun akad kafalah adalah Penjamin (Kafil), Pihak yang dijamin (Makful 'Anhu), Pihak yang berpiutang (Makful Lahu), Objek (Makful Bihi), dan Akad.

3) Akad kafalah dalam kegiatan perbankan syariah digunakan sebagai salah satu bentuk jasa bank untuk menjamin kegiatan atau usaha yang diajukan oleh nasabah. Penjaminan dalam bentuk kafalah dapat dilakukan dengan model jaminan harta (kafalah bi al-mal) dan jaminan orang/lembaga (kafalah bi al-nafs). Secara finansial atau kelembagaan bank menjamin pihak yang mengajukan jasa penjaminan 


\section{Daftar Pustaka}

'Ali al-Khafif, (200), al-Daman fi al-Figh al-Islami, al-Qahirah: Dar al-Fikr al- 'Arabi, 2000.

Adiwarman A. Karim, (2001), Ekonomi Islam: Suatu Kajian Kontemporer (Jakarta: Gema Insani.

Dewan Syariah Nasional, (2001), Himpunan Fatwa DSN-MUI, Jakarta: Majlis Ulama Indonesia. .

Fatwa Dewan Syariah Nasional (DSN) Nomor 11/DSN-MUI/IV/ 2000 tentang Kafalah.

Hendi Suhendi, 2010), Figh Muamalah, Jakarta: Raja Grafindo Persada.

Krismawati Weni, Robiatul Auliyah,Yuni Rimawati, (2013), "Kajian Kafalah pada Koprasi Jasa Keuangan Syariah As-Sakinah di Kamal Bangkalan", Jurnal InFestasi.Vol.9. No.2 Desember 2013.

M. Syafi'i Antonio, (2001), Bank Syari'ah: Dari Teori ke Praktek (Jakarta: Tazkia Cendeki.

Mugiati. 2014. Kajian Hukum IslamTerhadap Aplikasi Kafalah pada Asuransi Takaful". Jurnal Al-Quran,Volume 17,Nomor 1.

Peraturan Mahkamah Agung Nomor 2 Tahun 2008 tentang Kompilasi Hukum Ekonomi Syariah.

Sayyid Sabiq, (1981), Fiqh As-Sunnah, Beirut: Dar Al-Fikr..

Wahbah Zuhaili, (2002), Al-Figh al-Islamy wa Adillatuhu, Beirut: Dar al-Fikr. 